\title{
Intermetallic eutectic alloys in the Ni-Al-Zr system with attractive high temperature properties
}

\author{
Chandrasekhar Tiwary, Vilas V. Gunjal, Dipankar Banerjee, and Kamanio Chattopadhyay ${ }^{\mathrm{a}}$ \\ Department of Materials Engineering Indian Institute of Science, Bangalore 560012, India
}

\begin{abstract}
We describe a group of alloys with ultrahigh strength of about $2 \mathrm{GPa}$ at $700^{\circ} \mathrm{C}$ and exceptional oxidation resistance to $1100^{\circ} \mathrm{C}$. These alloys exploit intermetallic phases with stable oxide forming elements that combine to form fine nanometric scale structures through eutectic transformations in ternary systems. The alloys offer engineering tensile plasticity of about $4 \%$ at room temperature though both conventional dislocation mechanisms and twinning in the more complex intermetallic constituent, along with slip lengths that are restricted by the interphase boundaries in the eutectics.
\end{abstract}

\section{Introduction}

Intermetallics such as $\mathrm{Ni}_{3} \mathrm{Al}$ and $\mathrm{NiAl}$ have been extensively evaluated for high temperature alloy systems and indeed have been used for several decades in the classical $\mathrm{Ni}$ base superalloys which derive their high temperature strength from nanoscale dispersions of the aluminide, $\mathrm{Ni}_{3} \mathrm{Al}\left(\gamma^{\prime}\right)$ in a matrix of disordered fcc $\mathrm{Ni}$ $(\gamma)$, alloyed with expensive, high density, refractory elements such as $\mathrm{Re}$ and $\mathrm{Ru}$. We describe a new alloy system based on intermetallic phases realised from solidification of compositions in the $\mathrm{Ni}-\mathrm{Al}-\mathrm{Zr}$ system. Our choice of alloy compositions was based on an earlier assessment of equilibria and liquidus projections [1-3]. We have identified in this system three binary eutectics, $\operatorname{NiAl}(\beta)+\mathrm{Ni}_{7} \mathrm{Zr}_{2}(\tau), \mathrm{Ni}_{3} \mathrm{Al}\left(\gamma^{\prime}\right)+$ $\mathrm{Ni}_{7} \mathrm{Zr}_{2}(\tau), \mathrm{Ni}_{3} \mathrm{Al}\left(\gamma^{\prime}\right)+\mathrm{Ni}_{5} \mathrm{Zr}(\varepsilon)$ and a ternary eutectic $\mathrm{NiAl}+\mathrm{Ni}_{3} \mathrm{Al}+\mathrm{Ni}_{7} \mathrm{Zr}_{2}$, We have evaluated the mechanical behaviour of these in compression as a function of temperature, and in some cases in tension at room temperature. We have also assessed the oxidation behaviour of these alloys. The alloys show ultrahigh strength to temperatures of $700^{\circ} \mathrm{C}$ and attractive oxidation resistance and high temperature structural microstructural stability. The high strength is accompanied by tensile plasticity.

\section{Experimental}

Alloys were non-consumable vacuum remelted several times into $50 \mathrm{gm}$ buttons and suction cast into $3 \mathrm{~mm}$ diameter rods. The composition of the alloys that were examined in this study are shown in Fig. 1 as well as in Table 1.

The as-melted alloys were characterised by optical microscopy, scanning electron microscopy (SEM), and

\footnotetext{
${ }^{a}$ Corresponding author: karthik@materials.iisc.ernet.in
}

electron probe microanalysis (EPMA). Samples for transmission electron microscopy were prepared by either electropolishing in a solution of picric acid, glycerol and ethanol at a temperature of $5^{\circ} \mathrm{C}$, or by ion milling.

Both compression ( $3 \mathrm{~mm}$ diameter and $4.5 \mathrm{~mm}$ height) and flat microtensile samples (thickness $2 \mathrm{~mm}$, gauge length $10 \mathrm{~mm}$ ) were prepared from the suction cast rods. These samples were polished prior to testing to permit the examination of slip lines after tests. Fracture surfaces of the tensile samples were also examined to elucidate fracture modes at room temperature.

Oxidation experiments were carried out in air with continous weight measurements using a micro balance with a sensitivity of about $100 \mu \mathrm{g}$. Samples with flat polished surfaces were used in the oxidation tests.

\section{Results}

\subsection{Microstructure}

Microstructures of fully eutectic alloys are shown in Fig. 2. These alloys lie essentially along the $11 \% \mathrm{Zr}$ section. We have identified in this section a variety of eutectic combinations that form under the cooling conditions that are realised experimentally. These are $\mathrm{Ni}_{3} \mathrm{Al}+\mathrm{Ni}_{5} \mathrm{Zr}$ in alloy $\mathrm{E} 1, \mathrm{Ni}_{3} \mathrm{Al}+\mathrm{Ni}_{7} \mathrm{Zr}_{2}$ in alloy $\mathrm{E} 2$ $\mathrm{NiAl}+\mathrm{Ni}_{7} \mathrm{Zr}_{2}$ in alloy $\mathrm{E} 3$ and the ternary eutectic $\mathrm{NiAl}+\mathrm{Ni}_{3} \mathrm{Al}+\mathrm{Ni}_{7} \mathrm{Zr}_{2}$ in alloy $\mathrm{TE}$. The eutectic colonies in alloy E3 show a central lamellar structure that degenerates to a more irregular appearance at the boundaries. The eutectic in alloy E2 consists of an extremely fine fibrous structure, while the eutectic in alloy E1 again has a central fine lamellar structure surrounded by a coarser irregular lamellar morphology The ternary eutectic shows the phases in dark $(\mathrm{NiAl})$, light grey $\left(\mathrm{Ni}_{3} \mathrm{Al}\right)$, and light contrast $\left(\mathrm{Ni}_{7} \mathrm{Zr}_{2}\right)$. Combinations of the binary eutectics $\mathrm{Ni}_{3} \mathrm{Al}+\mathrm{Ni}_{7} \mathrm{Zr}_{2}$ and $\mathrm{NiAl}+\mathrm{Ni}_{7} \mathrm{Zr}_{2}$ are realised in alloys $\mathrm{ME2} / 3$ and $\mathrm{ME} 3 / 2$, with the latter containing greater

This is an Open Access article distributed under the terms of the Creative Commons Attribution License 4.0, which permits unrestricted use, distribution, and reproduction in any medium, provided the original work is properly cited. 


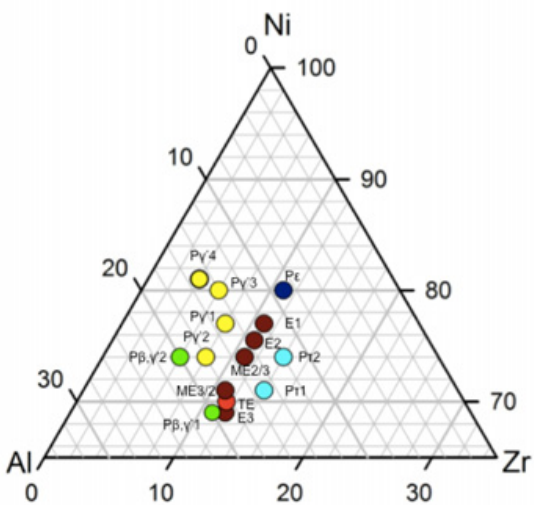

Figure 1. Alloy compositions are designated to show binary eutectic compositions (E and ME), a ternary eutectic (TE) and compositions with primary intermetallic solidification phases $(\mathrm{P})$.

Table 1. Alloy designations indicate binary eutectics (E), mixtures of binary eutectics (ME), a ternary eutectic (TE) and compositions with primary phase compositions $(\mathrm{P})$.

\begin{tabular}{|l|c|c|c|}
\hline Designation & $\mathrm{Al}$ & $\mathrm{Zr}$ & $\mathrm{Ni}$ \\
\hline $\mathrm{E} 1$ & 12 & 11 & 77 \\
\hline $\mathrm{E} 2$ & 13.5 & 11 & 75.5 \\
\hline $\mathrm{E} 3$ & 19 & 12 & 69 \\
\hline $\mathrm{TE}$ & 18.4 & 11.6 & 70 \\
\hline $\mathrm{ME} 2 / 3$ & 15 & 11 & 74 \\
\hline $\mathrm{ME} 3 / 2$ & 18 & 11 & 71 \\
\hline $\mathrm{P} \varepsilon$ & 9 & 11 & 80 \\
\hline $\mathrm{P} \gamma^{\prime} 1$ & 15 & 8 & 77 \\
\hline $\mathrm{P} \gamma^{\prime} 2$ & 18 & 8 & 74 \\
\hline $\mathrm{P} \gamma^{\prime} 3$ & 14 & 6 & 80 \\
\hline $\mathrm{P} \gamma^{\prime} 4$ & 15 & 4 & 81 \\
\hline $\mathrm{P} \tau 1$ & 15 & 14 & 71 \\
\hline $\mathrm{P} \tau 2$ & 12 & 14 & 74 \\
\hline $\mathrm{P} \beta, \gamma^{\prime} 1$ & 20 & 11 & 69 \\
\hline $\mathrm{P} \beta, \gamma^{\prime} 2$ & 20 & 6 & 74 \\
\hline
\end{tabular}

amounts of the eutectic E3. Other alloys show the presence of primary solidification phases along with a eutectic (Fig. 3). Thus alloy $\mathrm{P} \gamma^{\prime} 1$ contains the primary $\mathrm{Ni}_{3} \mathrm{Al}$ phase while alloys $\mathrm{P} \beta, \gamma^{\prime} 1$ and $\mathrm{P} \beta, \gamma^{\prime} 2$ show the primary $\mathrm{NiAl}$ and $\mathrm{Ni}_{3} \mathrm{Al}$ phases. Alloy $\mathrm{P} \tau 1$ and $\mathrm{P} \tau 2$ has a primary $\mathrm{Ni}_{7} \mathrm{Zr}_{2}$ phase while alloy $\mathrm{P} \varepsilon$ contains the primary $\mathrm{Ni}_{5} \mathrm{Zr}$ phase.

\subsection{Mechanical behaviour}

Figure 4 shows the hardness and modulus of $\mathrm{Ni}_{3} \mathrm{Al}, \mathrm{Ni}_{5} \mathrm{Zr}$ and $\mathrm{Ni}_{7} \mathrm{Zr}_{2}$ determined by picohardness measurements on the primary solidification phases. We note that there is no prior report of the mechanical behaviour of the $\mathrm{Ni}_{5} \mathrm{Zr}$ and $\mathrm{Ni}_{7} \mathrm{Zr}_{2}$ phases available in the literature. The properties of the $\mathrm{NiAl}$ and $\mathrm{Ni}_{3} \mathrm{Al}$ phases as available in the literature are included in the Figure. $\mathrm{The}^{\mathrm{Ni}} \mathrm{Zr}_{2}$ has the highest hardness and modulus followed by the $\mathrm{Ni}_{5} \mathrm{Zr}$ phase.

These data were obtained with low load $(10 \mu \mathrm{N})$ picoindentation consisting of Berkovich indenter with a $\mathrm{SiC}$ tip. The low load indenter (PI 85 SEM PicoIndenter from Hysitron) is used in conjunctionwith a scanning electron microscope (SEM).

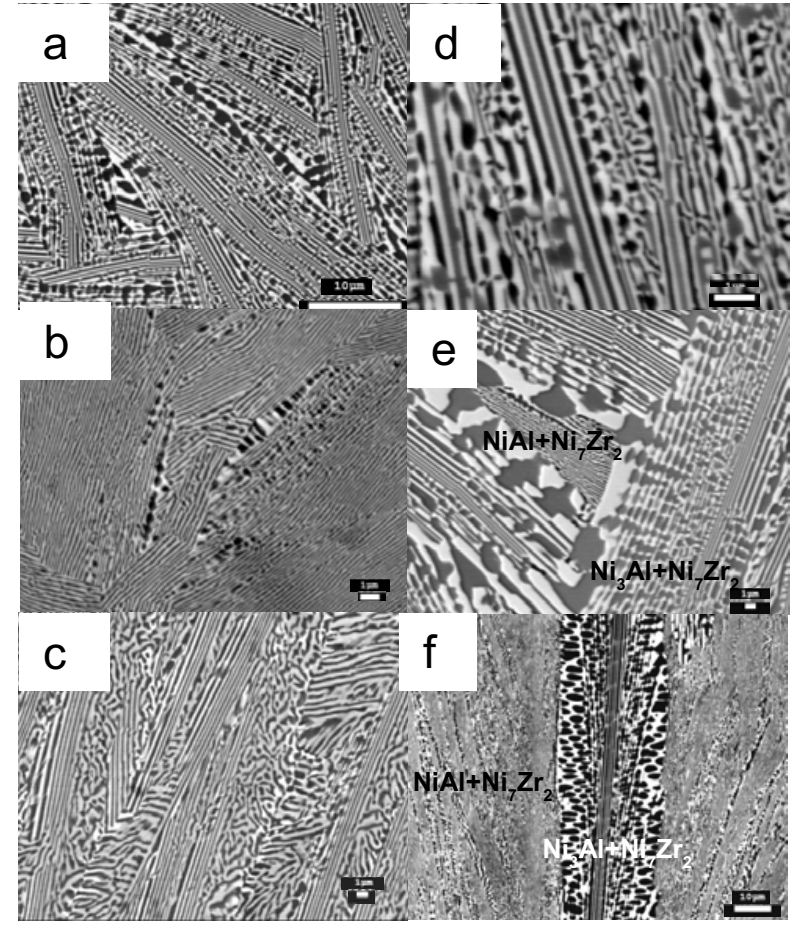

Figure 2. Eutectic structures: (a) alloy E3 (b) alloy (E2) (c) alloy E1 (d) alloy TE (e) alloy ME2/3 (d) alloy ME3/2.

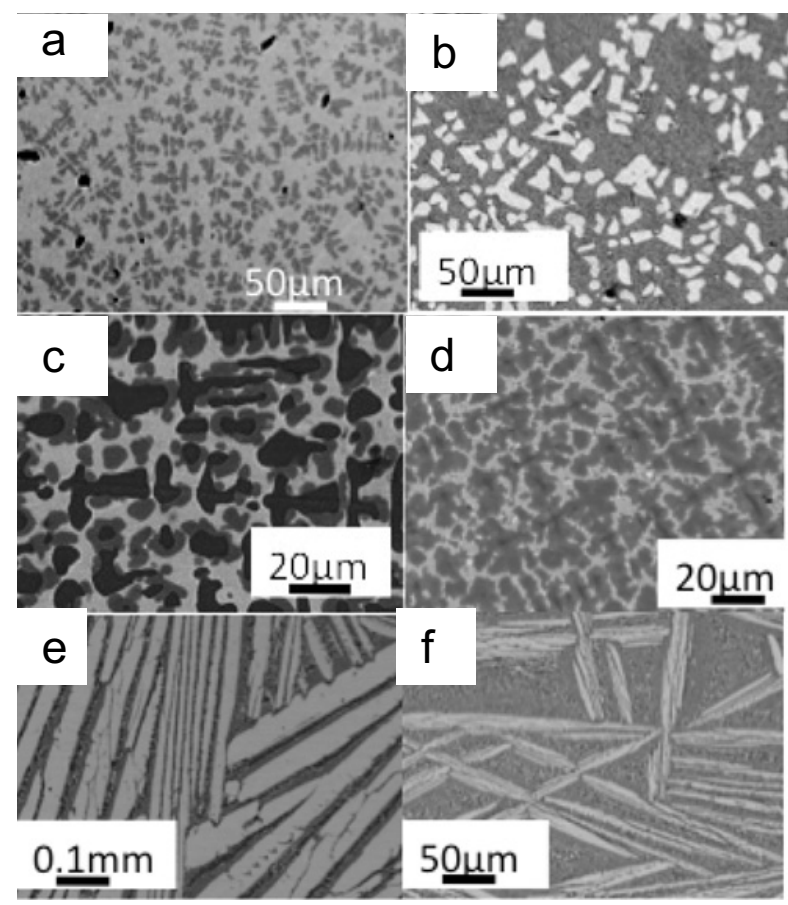

Figure 3. Alloys containing primary intermetallic phases: (a) alloy $\mathrm{P} \gamma^{\prime} 1$ (b) $\mathrm{P} \varepsilon$ (c) alloy $\mathrm{P} \beta, \gamma^{\prime} 1$ (d) alloy $\mathrm{P} \beta, \gamma^{\prime} 2$ (e) alloy $\mathrm{P} \tau 1$ (f) alloy $\mathrm{P} \tau 2$.

Figure 5 shows data from compression tests as a function of temperature for the eutectic alloys. The eutectic $\mathrm{Ni}_{3} \mathrm{Al}+\mathrm{Ni}_{5} \mathrm{Zr}$ has the highest strength of all the eutectics. The strength levels observed are significantly above those of typical Ni base superalloys. The strength levels persist to $700 \mathrm{C}$ and then drop significantly. 


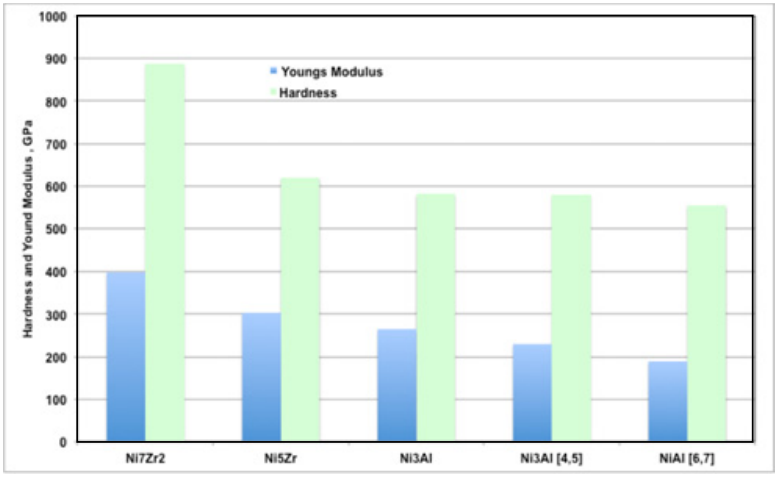

Figure 4. The hardness and modulus of intermetallic phases determined by picoindentation in alloys containing these phases as primary solidification phases.

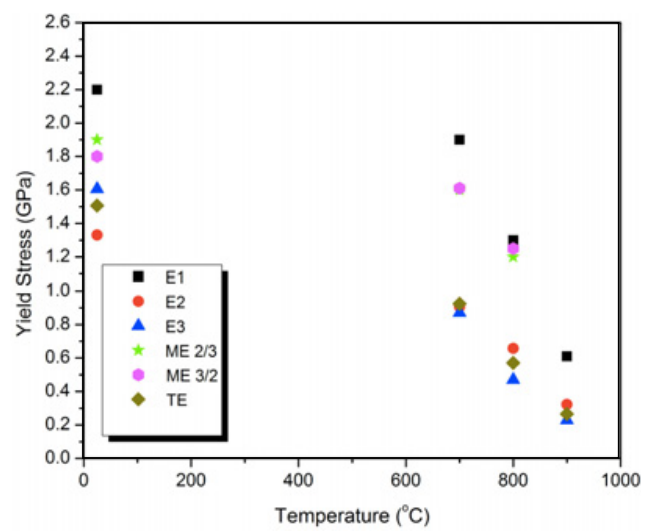

Figure 5. Yield strength in compression as function of temperature of the eutectic alloys.

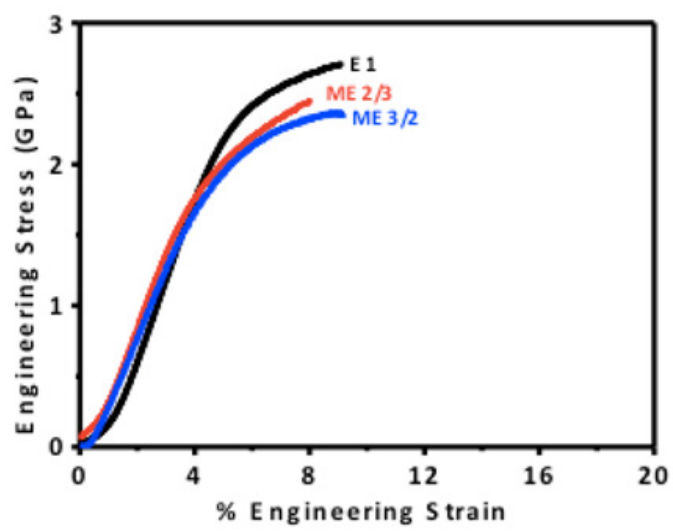

Figure 6. Tensile stress-strain curves of some eutectic alloys.

Tensile data at room temperature are shown in Fig. 6 for three of the alloys, one containing the eutectic $\mathrm{Ni}_{3} \mathrm{Al}+\mathrm{Ni}_{5} \mathrm{Zr}$ (alloy E1) and the others containing different proportions of the eutectics $\mathrm{Ni}_{3} \mathrm{Al}+\mathrm{Ni}_{7} \mathrm{Zr}_{2}$ and $\mathrm{NiAl}+\mathrm{Ni}_{7} \mathrm{Zr}_{2}$. Significant tensile plasticity of $3-4 \%$ is observed at these extremely high strength levels.

In Fig. 7, we show an example of failure initiation and fracture in tension from alloy E1 containing the $\mathrm{Ni}_{3} \mathrm{Al}+\mathrm{Ni}_{5} \mathrm{Zr}$ eutectic. Figure 2 shows that the eutectic exits in two length scales. Failure initiation occurs through void nucleation at the $\mathrm{Ni}_{3} \mathrm{Al} / \mathrm{Ni}_{5} \mathrm{Zr}$ interfaces in the coarser

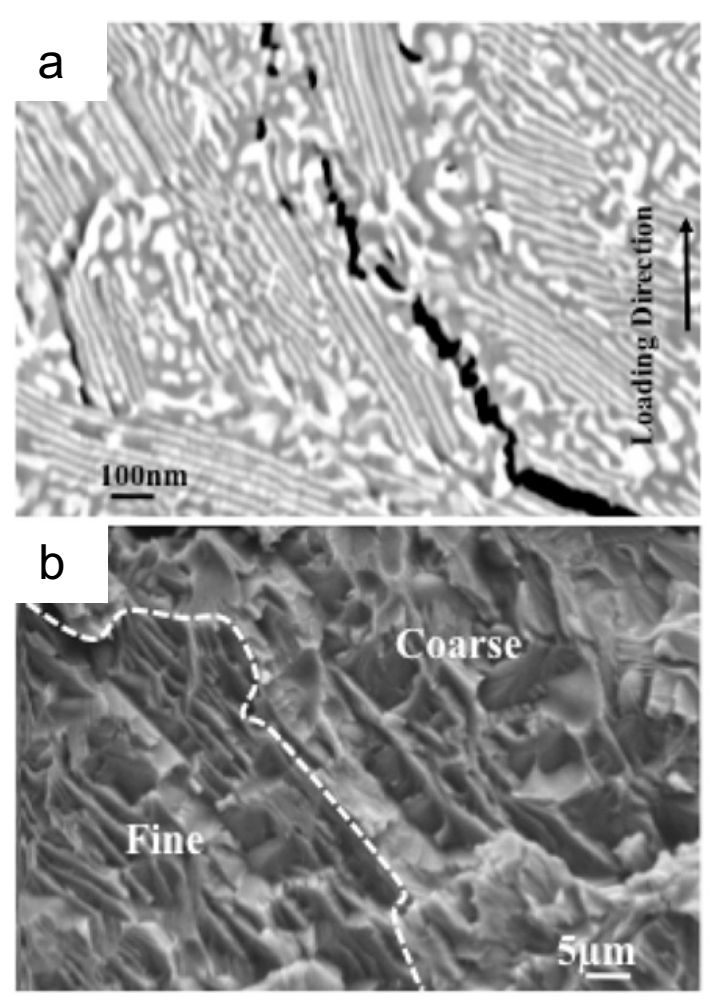

Figure 7. (a) Void nucleation and growth within the $\mathrm{Ni}_{3} \mathrm{Al}$ phase in alloy E1. (b) The fracture surface in tension.

segments of the microstructure and subsequently growth through the $\mathrm{Ni}_{3} \mathrm{Al}$ phase around $\mathrm{Ni}_{5} \mathrm{Zr}$. The resulting fracture surface has a macroscopically ductile appearance, with evidence for void formation in $\mathrm{Ni}_{3} \mathrm{Al}$ in both the fine, lamellar regions and the coarse irregular morphology of the eutectic.

The scale of fracture features is related to the fine submicron scale of the eutectic and the $\mathrm{Ni}_{5} \mathrm{Zr}$ lamellae probably fail by tearing of the lamellar ligaments after voids have formed within $\mathrm{Ni}_{3} \mathrm{Al}$. Thus deformation appears to occur by extensive plasticity within $\mathrm{Ni}_{3} \mathrm{Al}$ before it spreads to the stronger $\mathrm{Ni}_{5} \mathrm{Zr}$ phase. We have examined deformation structure within these intermetallic phases by transmission electron microscopy. Conventional deformation by dislocation-based plasticity is observed in $\mathrm{Ni}_{3} \mathrm{Al}, \mathrm{NiAl}$ and $\mathrm{Ni}_{5} \mathrm{Zr}$ (Fig. 8), while $\mathrm{Ni}_{7} \mathrm{Zr}_{2}$ deforms by an unusual microtwnning mechanism in the (Fig. 9).

We have also evaluated the effect of the presence of the primary intermetallic phases in the microstructure on room temperature strength in compression. Figure 10 shows this for two different base alloys, the E1 eutectic and the ME2/3 eutectic combination. In all cases the presence of primary phases lowers the strength

\subsection{Oxidation resistance}

Figure 11 shows oxidation data for alloys $\mathrm{E} 1\left(\mathrm{Ni}_{3} \mathrm{Al}\right.$ $\left.+\mathrm{Ni}_{5} \mathrm{Zr}\right)$ and $\mathrm{ME} 3 / 2\left(\mathrm{Ni}_{3} \mathrm{Al}+\mathrm{Ni}_{7} \mathrm{Zr}_{2}\right.$ and $\left.\mathrm{NiAl}+\mathrm{Ni}_{7} \mathrm{Zr}_{2}\right)$. These suggest that oxidation occurs in 3 distinct stages associated with different reaction kinetics.

An initial stage of very rapid oxidation is seen, followed by a transition stage to a steady state associated with progressively decreasing rate constants. In some 


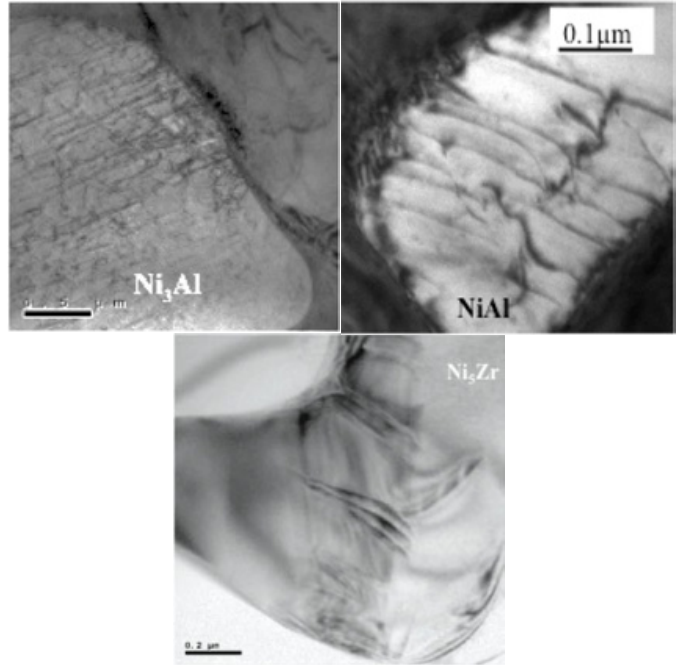

Figure 8. Dislocation structures in various intermetallic phases in the eutectics.

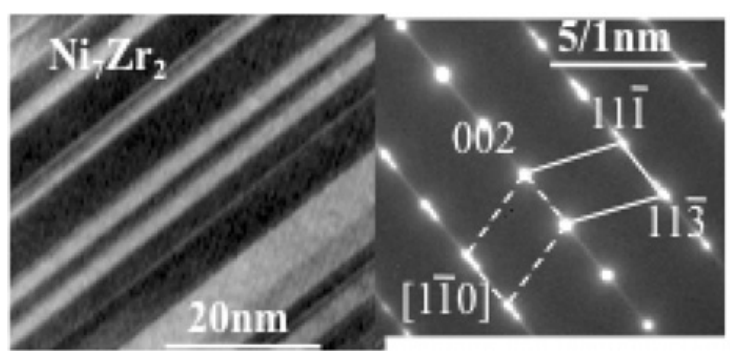

Figure 9. Microtwinning in $\mathrm{Ni}_{7} \mathrm{Zr}_{2}$.

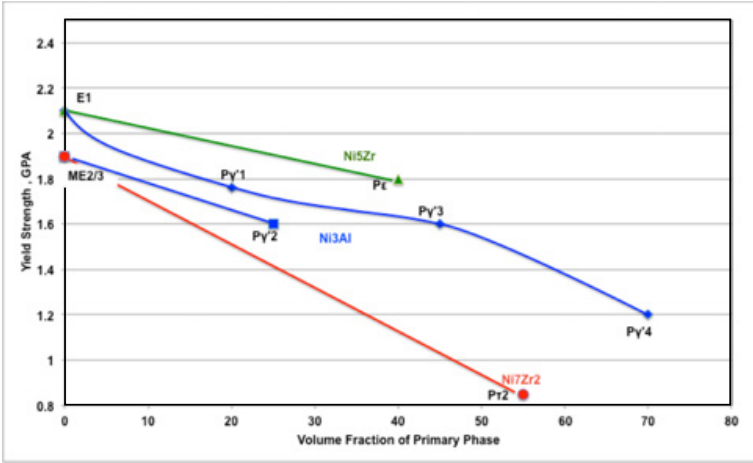

Figure 10. The effect of primary intermetallic phases in the microstructure on the yield strength at room temperature.

cases, particularly in alloy $\mathrm{C}$, there is evidence of instability in the oxidation curves that suggests spalling of the oxide layer in early stages before a final steady state regime is reached.

The rate constants associated with the steady state regime correspond to the rate constants that are associated with the oxidation of $\mathrm{Ni}_{3} \mathrm{Al}$ and $\mathrm{NiAl}$ and superalloys with $\mathrm{Al}_{2} \mathrm{O}_{3}$ or spinel formation rather than the formation of the $\mathrm{NiO}$ or $\mathrm{Zr}_{2} \mathrm{O}_{3}$ phases which are associated with rate constants that are orders of magnitude higher (Fig. 12). The significantly larger rate constant associated with the initial rapid oxidation phase is more likely to be associated with the initial formation of the latter oxides.
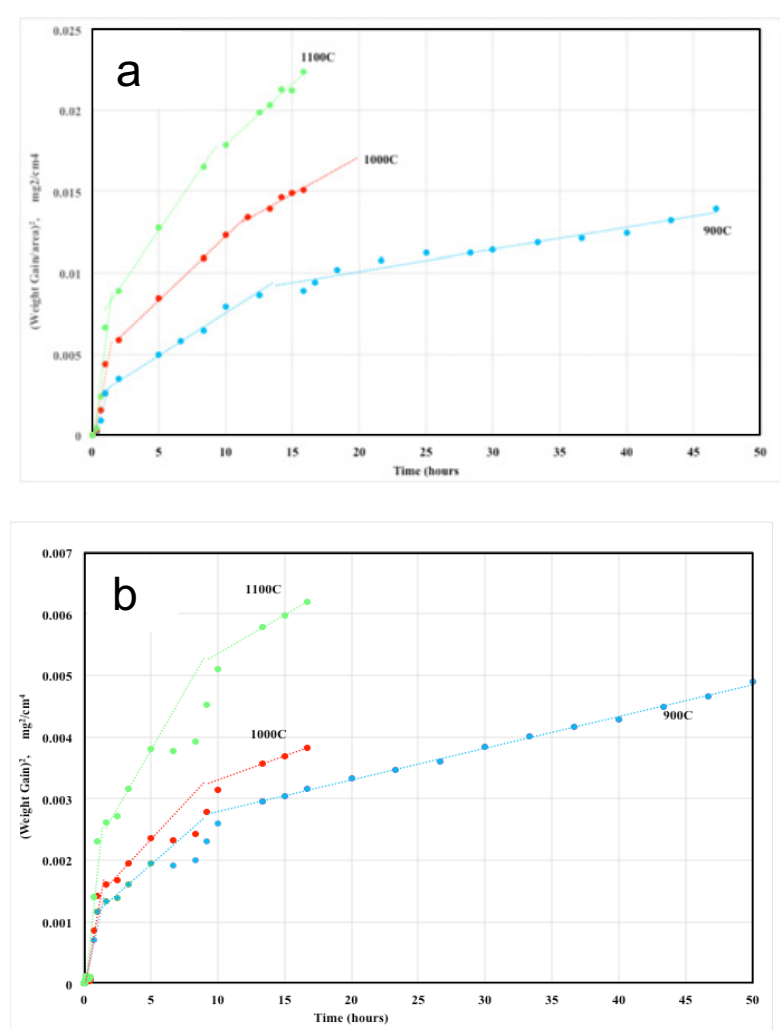

Figure 11. Plots of the square of weight gain against time in (a) alloy E1 and (b) alloy ME3/2.

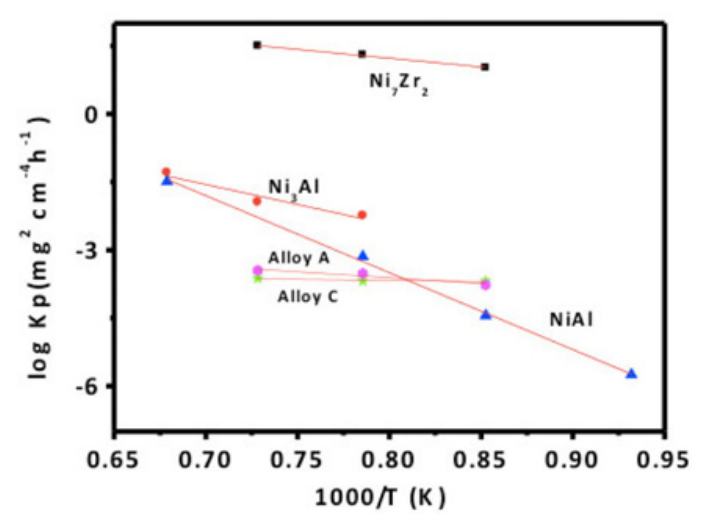

Figure 12. Activation plots for $\mathrm{Ni} 3 \mathrm{Al}, \mathrm{NiAl}, \mathrm{Ni} 7 \mathrm{Zr} 2$ and alloys $\mathrm{E} 1$ (A in figure) and ME2/3 (C in figure). Data for $\mathrm{Ni}_{5} \mathrm{Zr}$ from [8] and $\mathrm{NiAl}$ and $\mathrm{Ni}_{3} \mathrm{Al}$ from [9].

However the activation energies in the steady state regime are significantly lower than those associated with the oxidation of $\mathrm{Ni}_{3} \mathrm{Al}$ or $\mathrm{NiAl}$ which correspond more generally to $\mathrm{Al}_{2} \mathrm{O}_{3}$ formation or to the formation of mixed oxides of $\mathrm{NiO}, \mathrm{Al}_{2} \mathrm{O}_{3}$ and spinel. In fact these activation energies correspond to no known oxidation or diffusion processes. As we shall see below the microstructure of the oxygen affected layers in these alloys are considerably more complex and indicative of several processes that operate simultaneously. It is thus not possible to correlate these apparent activation energies with any one simple process. 

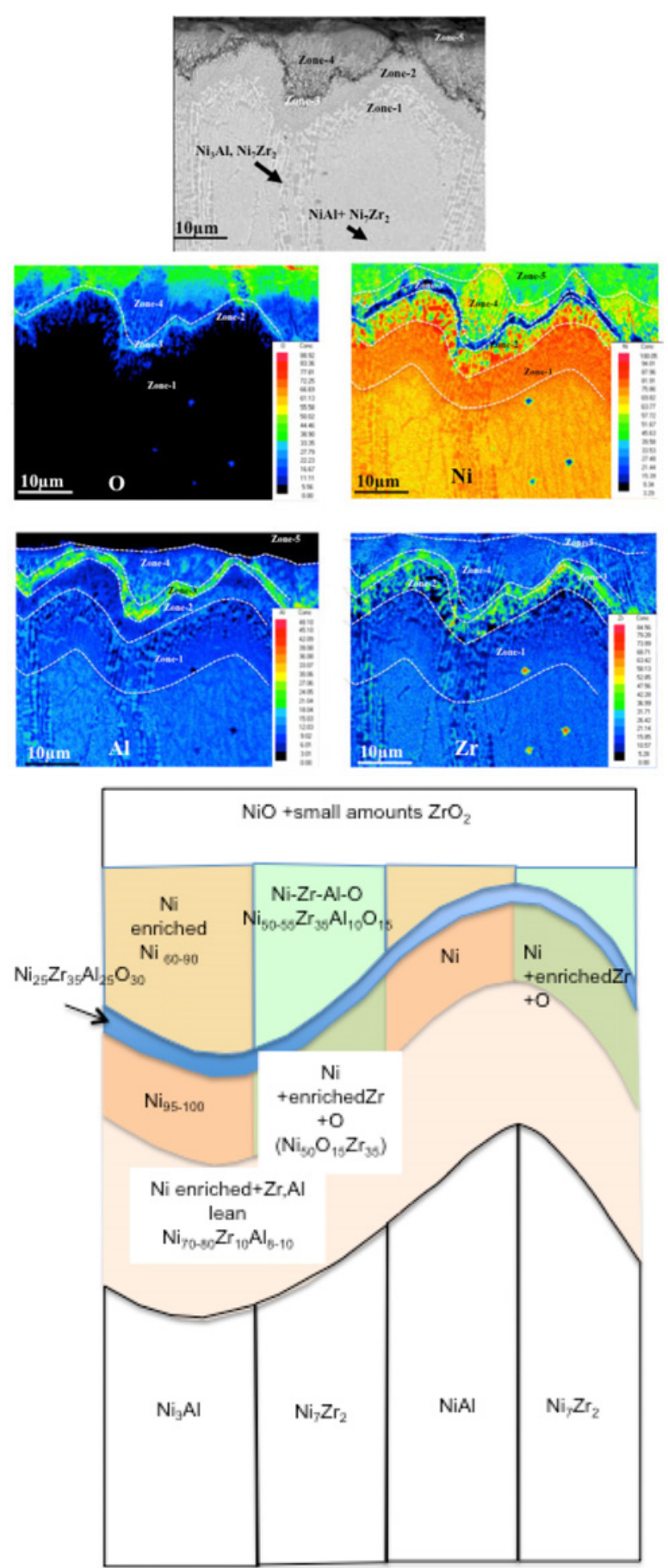

Figure 13. Microstructure of the oxidized layer of alloy ME2/3 after $16 \mathrm{hr}$ at $900 \mathrm{C}$ and a schematic description of the structure magnified at the scale of the eutectic.

Figure 13 shows the crossection of the oxidized layer in alloy ME3/2 after 16 hours at 900C. An outermost layer, Zone 5, is composed of $\mathrm{NiO}$ and $\mathrm{ZrO}_{2}$ (no $\mathrm{Al}$ is present in this layer). Zone 4 consists of $\mathrm{Zr}$ rich and $\mathrm{Ni}$ rich regions. The intermediate layers between zone 1 and zone 4 consist of a thin $\mathrm{Ni}$ depleted $\mathrm{Al}, \mathrm{Zr}$ and $\mathrm{O}$ rich layer (zone 3). A layer, zone 2, containing relatively lower amounts of $\mathrm{Al}, \mathrm{Zr}$ and $\mathrm{O}$ is present between zone 3 and zone 1 . Zone 3 and 2 do not contain oxides of $\mathrm{Al}$ or $\mathrm{Zr}$ The composition range
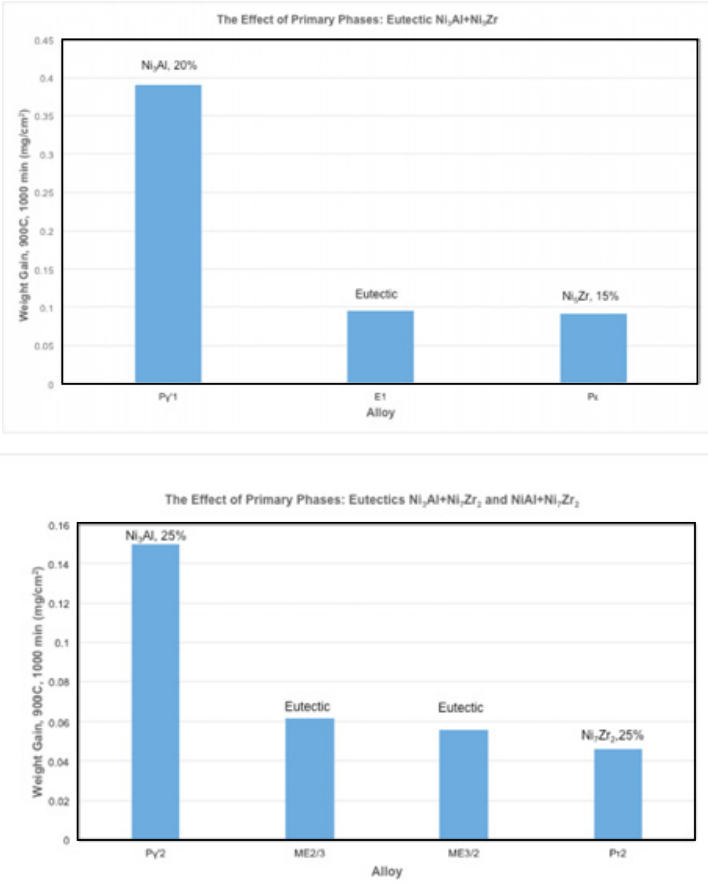

Figure 14. Weight gain in alloys containing primary intermetallic phases in comparison to fully eutectic structures.

of zone 3 suggests that this region might be composed primarily of the intermetallic NiAlZr. Zone 1 is marginally depleted in $\mathrm{Zr}$ and $\mathrm{Al}$ and therefore enriched in $\mathrm{Ni}$ but not substantively altered in microstructure. A detailed analysis of the EPMA images leads to the schematic description of the oxygen affected crosssection shown in Fig. 13. The following steps may be envisaged for the evolution of the oxygen-affected microstructure

(i) $\mathrm{O}$ ingress into the $\mathrm{Ni}_{5} \mathrm{Zr}$ intermetallic in solid solution.

(ii) The formation of $\mathrm{NiO}$ by the outward diffusion of $\mathrm{Ni}$ from $\mathrm{Ni}_{5} \mathrm{Zr}$ and $\mathrm{Ni}_{3} \mathrm{Al}$.

(iii) Interaction of $\mathrm{Al}$ and $\mathrm{Zr}$ in the base metal with oxygen at the $\mathrm{NiO}$ scale /metal interface to form $\mathrm{Ni}-\mathrm{Al}-\mathrm{Zr}-\mathrm{O}$ complexes in the intermediate layers.

The presence of $\mathrm{Ni}_{3} \mathrm{Al}$ as a primary solidification phase lowers the oxidation resistance, while the presence of the $\mathrm{Zr}$ rich intermetallics does not affect the oxidation resistance compared with the baseline eutectic alloys as shown by the weight gain data in Fig. 14.

\section{Summary}

In summary, we find that submicron scale eutectic structures in the $\mathrm{Ni}-\mathrm{Al}-\mathrm{Zr}$ systems comprised of the $\mathrm{Ni}_{3} \mathrm{Al}, \mathrm{NiAl}, \mathrm{Ni}_{5} \mathrm{Zr}$ and $\mathrm{Ni}_{7} \mathrm{Zr}_{2}$ intermetallics offer very high strength combined with reasonable tensile plasticity at room temperature under the processing conditions that have been explored in this study. Certainly the more complex intermetallic phases $\mathrm{Ni}_{5} \mathrm{Zr}$ and $\mathrm{Ni}_{7} \mathrm{Zr}_{2}$ are 
expected to be brittle in room temperature. Nevertheless, under the fine scale, constrained deformation conditions that have been engineered in these microstructures, we see no evidence of brittle behaviour. This exceptional mechanical behaviour is complemented with extremely good high temperature structural stability and oxidation resistance. It is tempting to speculate that stability of the oxide scales is also related to the scale of the underlying microstructure and distribution of alloying elements that react form submicron or nano-grained dispersions of mixed oxides. Considering in addition the low densities of these alloys, ranging from $7.35-7.95 \mathrm{gm} / \mathrm{cc}$, and the relatively low cost of the constituent elements, this system is clearly of great potential for high temperature applications.

Two of the authors KC and DB are grateful for support from the J.C. Bose Fellowship of the Department of Science and Technology, India. The use of facilities at AFMM, Indian Institute of Science is gratefully acknowledged.

\section{References}

[1] S. Miura, H Unno, T. Yamazaki, S.Takizawa, and T. Mohri, Journal of Phase Equilibria 22, 457 (2001)

[2] Thompson, E.R., Lemkey, F.D., Trans. ASM, 62, 140 (1969)

[3] G. Ghosh in MSIT, (Landolt Bornstein New series 11A3:1-13 2005), pp 451-463

[4] F. X. Kayser And C. Stassi, phys. stat. sol. (a) 64, 335 (1981)

[5] P. Hyjek, I. Sulima, S. Wierzbiñski, Archives of Materials Science and Engineering, 40, 69 (2009)

[6] D. B. Miracle, Acta metall, mater. 41, 649 (1993)

[7] P. Nash, U.C. Ur, and M. Dollar in Proc. 2nd Int. Conf. Struct. Appl. Mech. Alloying. Vancouver, Canada, 1993. (ASM International, Materials Park, OH) p. 192

[8] V. G. Chuprina, I. M. Shalya, Powder Metallurgy and Metal Ceramics, 43, 9 (2004)

[9] In, Intermetallic Compounds: Practice, J. H. Westbrook, R. L. Fleischer (John Wiley and Sons, 1995) 